\title{
Effect of inoculation of two Aztobacter and nitrogen fertilizer on of peppermint (Mentha piperita) essential oil
}

\author{
REZA DEHGHANI BIDGOLI \\ Department of Rangeland and Watershed Management, Faculty of Natural Resources and Earth Sciences, University of Kashan. Qotb-e Ravandi Blvd, \\ Isfahan Province, 87317-53153, Iran. Tel./fax.: +98-31-55913240, `email: dehghanir@kashanu.ac.ir \\ Manuscript received: 5 February 2019. Revision accepted: 9 March 2019.
}

\begin{abstract}
Bidgoli RD. 2019. Effect of inoculation of two Aztobacter and nitrogen fertilizer on of peppermint (Mentha piperita) essential oil. Asian J Agric 3: 22-25. This study was conducted to study changes of percentage and yield of essential oil of peppermint (Mentha piperita) as a split factorial in a randomized complete block design (RCBD) with three replications in 2016-2017. The experimental treatments were nitrogen at four levels $0,50,100$ and $150 \mathrm{~kg} / \mathrm{ha}$ as the main factor and two strains of PGPR (Azotobacter chroococcum MZ11, MZ26) in two states of (use and non-use) was considered as subfactors. Results showed that use of these two A. chroococcum strains has led to an increase in the percentage and yield of peppermint essential oil more than all Nitrogen fertilizer treatments. Also, the highest peppermint essential oil percentage $(0.73 \%)$ was obtained in the triple interaction of Nitrogen (100 kg/ha) A. chroococcum MZ11 and A. chroococcum MZ26. The highest essential oil yield $(91.65 \mathrm{~kg} / \mathrm{ha})$ was observed under the influence of the triple interaction of Nitrogen (100 kg/ha), A. chroococcum MZ11 and A. chroococcum MZ26.
\end{abstract}

Keywords: Aztobacter chroococcum, essential oil, fertilizer, peppermint, plant yield

\section{INTRODUCTION}

This study was carried out to investigate the effect of biofertilizers on the essential oil of peppermint in 2018. Peppermint (Mentha piperita L.), which belongs to the family Lamiaceae, is a hybrid species obtained from the confluence of Mentha spicata and Mentha aquatica species (Foster 1996; Peirce 1999). This plant species is a perennial plant, with a height of 50 to $60 \mathrm{~cm}$, a quadrangular stalk that is usually purple in color and smooth (Govedarica et al. 2003). The global peppermint essential oil production is about 8,000 tons/year. The main compounds of peppermint essential oil are menthol (29\%), menthon (20-30\%), and methyl acetate (1 to $3 \%$ ). Extraction of peppermint essential oil from the aerial parts of the plant at the beginning of the flowering stage is usually by steam distillation method. About 30 to $70 \%$ of its essential oil is menthol and esters of menthol, and the rest are more than 40 other compounds (Afzal 2010). Other compounds found in the peppermint essential oil include flavonoids (12\%), polymerized polyphenols (19\%), carotene, tocopherol betaine and choline (Murrray 1995). Currently, peppermint is used for the treatment of irritable bowel syndrome (IBS), inflammatory bowel disease (Crohn and ulcerative colitis), gallbladder inflammation, biliary system defects and liver problems (Blumenthal 1998; Fleming 1998).

Peppermint is a long day plant (LDP), and its planting in long day conditions leads to increase in its production and yield. (Okan et al. 2004). Singh and Chatterjee (1989) stated that nitrogen increases the vegetative growth in the plant and leaf area index, number of sub-branches and flowering branches, for example in Mentha sativa, with use of $150 \mathrm{~kg} / \mathrm{ha}$ nitrogen obtained the highest of desired traits.
Anvar et al. (2005) found that the application of $100 \mathrm{~kg} / \mathrm{ha}$ nitrogen fertilizer increased the number of branches, number of leave pigments and the dry matter per unit and yield of essential oils. Masto et al. (2006) studied the effect of micronutrients and planting density on essential oil content and essential oil yield of the peppermint plant, and reported that the solution spraying of microelements produced the highest essential oil yield.

Valad Abadi et al. (2008) reported on the effects of different levels of drought stress and nitrogen on the Calendula officinalis L. and showed the effect of nitrogen on the percentage essential oil yield was significant at $(1 \%$ level). Akbarinia et al. (2012) evaluated effect of fertilizer on the percentage and yield of Trachyspermum ammi essential oil. They stated with increasing nitrogen and phosphorus, grain yield increased up to 90 and $60 \mathrm{~kg} / \mathrm{ha}$, respectively. Chemical fertilizers had no effect on essential oil percentage and $60 \mathrm{~kg} / \mathrm{ha}$ nitrogen, $40 \mathrm{~kg} / \mathrm{ha}$ phosphorus and 25 tons of manure per hectare and $60 \mathrm{~kg} / \mathrm{ha}$ nitrogen with 15 tons manure per hectare produced the highest grain and essential oil yield. Imam et al. (2014) reported that the use of nitrogen fertilizers increases the size, longevity, and freshness of leaves and shoots in the plant.

Also, Balyan and Sobti, (1990) reported that application rate of $80 \mathrm{~kg} / \mathrm{ha}$ nitrogen resulted in the accumulation and highest increase of dry matter in basil. Indiscriminate use of chemical fertilizers, most especially, nitrogen, coupled with lack of organic fertilizers in recent years, has resulted in significant reductions in the amount of organic matter in Iranian agricultural soils (Malekooti 2018). Green fertilizers are plants that are modified to improve the physical, chemical, and biological properties of soils, and to supply essential nutrients for optimum plant growth in 
successive growing seasons (Cherr et al. 2016). In fact, increased plant growth by inoculation of Azotobacter, has been attributed to the hormones produced by these bacteria and root growth (Zaied et al. 2003). The use of green fertilizers in addition to nitrogen fertilizers causes the nutrients to be readily available for crop production during the growing season and achieves more performance compared to the sole application of chemical fertilizers (Aktar et al. 1993; Paramanic et al. 2014).

\section{MATERIALS AND METHODS}

\section{Plant cultivation}

This study was conducted in a split factorial randomized complete block design (RCBD) with 3 replications from fall 2016 to spring 2017. The nitrogen factor of urea source at four levels, $0,50,100,150 \mathrm{~kg} / \mathrm{ha}$ as the main factor and two types of Azotobacter (Azotobacter chroococcum MZ11, MZ26) in two states (use and nonuse) as sub-factor were considered.

Rooted branches with lengths of 8 to $10 \mathrm{~cm}$ were cut from 2- to 3-year-old plants at 3 leaf stage and cultivated in 12 plots (4 treatments with 3 replications) of $25 \mathrm{~m}^{2}$. The selected plants were same in terms of size and height and based on the main and subfactors. The nitrogen at four levels $0,50,100$ and $150 \mathrm{~kg} / \mathrm{ha}$ were the main factors and other treatments were divided into 4 groups $\mathrm{N}_{0 \text { : }}$ (MZ11, MZ26), N50: (MZ11, MZ26),), $\mathrm{N}_{100:}$ (MZ11, MZ26)), $\mathrm{N}_{150}$ : (MZ11, MZ26). The nitrogen treatments herein were applied as done previously to investigate the interaction of the treatments. Planting was done in early January and due to the high sensitivity of Mentha piperita to drought stress in the region, irrigation was carried out every 4 days. Also, weed control was done manually owing to the experimental design adopted and the medicinal properties of the peppermint plant, from the beginning of the vegetative stage to the end, weeding was carried out continuously. There was no incidence of pest invasion, hence chemical pest control was not carried out. This was achieved because of the scent emitted by the plant. Physical and chemical properties of soil are presented in Table 1.

Table 1. Physical and chemical properties of farm soil

\begin{tabular}{lr}
\hline Soil property & Value \\
\hline $\mathrm{Cu}(\mathrm{ppm})$ & 1.60 \\
$\mathrm{Mg}(\mathrm{ppm})$ & 24.80 \\
$\mathrm{Mn}(\mathrm{ppm})$ & 9.88 \\
$\mathrm{P}(\mathrm{ppm})$ & 12.50 \\
$\mathrm{~K}(\mathrm{ppm})$ & 255.00 \\
$\mathrm{~N}(\mathrm{ppm})$ & 0.08 \\
$\mathrm{CaCO}(\mathrm{ppm})$ & 6.00 \\
$\mathrm{Texture}$ & $\mathrm{Loam}$ \\
Sand $(\%)$ & 38.00 \\
$\mathrm{Silt}(\%)$ & 35.00 \\
$\mathrm{Clay}(\%)$ & 27.00 \\
& \\
\hline
\end{tabular}

After harvest operations, the yield of fresh weight was determined immediately and to determine the yield of dry weight, samples were dried at room temperature $\left(25^{\circ} \mathrm{C}\right)$ and in shade for 10 days and then weighed. In order to determine the percentage and yield of Mentha piperita essential oil obtained from the different treatments, the plant samples were dried and weighed at room temperature and in shade. The samples were subjected to laboratory analyses, wherein essential oil was obtained by the water distillation method. The Clevenger device was used to calculate the essential oil percentage dehydration by dry Sodium sulfate $\left(\mathrm{Na}_{2} \mathrm{SO}_{4}\right)$. The essential oil yield was obtained from the multiplication of the essential oil percentage in the biological function divided to 100. Data were analyzed by MSTAT-C software, and mean comparison was carried with Duncan's method at $1 \%$ level of significance.

\section{RESULTS AND DISCUSSION}

\section{Essential oil percentage}

The results presented in Table 2 show that the individual effect of nitrogen on essential oil percentage of Mentha piperita was significant at 5\% level and two $A$. chroococcum strains were significant at $1 \%$ level. According to Table 3 and the results of the independent effect of the treatments, the lowest and highest essential oil percentages were obtained from the control nitrogen (mean $=0.15 \%$ ), and the A. chroococcum MZ26 treatment (mean $=0.44 \%$ ), respectively. Omid Beigi (1995) and Anvar et al. (2005) reported that the application of $100 \mathrm{~kg}$ of nitrogen would increase the yield of the branches, the number of leaves, pigment of leaves and increase of dry matter yield per unit area and yield of essential oil. Also, Bist et al. (2000) found that with addition of nitrogen fertilizer to soil, percentage, and some components of Anethum graveolens essential oil increased.

These observations could be attributed to the soil's ability to retain more moisture because of improved soil structure upon the incorporation of the PGPR treatments. This ultimately resulted in the increased biological yield of the peppermint plant and its essential oil yield. On the other hand, the increase in essential oil from the application of different fertilizer treatments could be due to the readily availability of nutrients, such as nitrogen and phosphorus, for the formation of ATP and NADPH, which serve in the pathway to the formation of terpenoids and isoprenoids in the essential oils (Loomis and Corteau 1972).

The interactions of nitrogen fertilizer with incorporated A. chroococcum MZ11 and A. chroococcum MZ26 on the percentage of essential oil were significant at $5 \%$ and $1 \%$ levels respectively, however, their triple effect was not significant (Table2). In the double interaction of Nitrogen and this two A. chroococcum, results showed the highest percentage of essential oil was obtained from $150 \mathrm{~kg} / \mathrm{ha}$ nitrogen in combination with incorporated A. chroococcum MZ11 (0.62\%), and the lowest essential oil percentage, obtained from the interaction of these two A. chroococcum (MZ11 and MZ26)as $0.16 \%$ (Table 4). In the essential oil 
yield, the highest and lowest values were obtained in these treatments too in a similar study, Valad Abadi et al. (2008) investigated the effects of different levels of nitrogen on Calendula officinalis and concluded that nitrogen increased the percentage and yield of its seed oil.

The interaction of $A$. chroococcum MZ11 and $A$. chroococcum MZ26 on the percentage of essential oil was significant at $5 \%$ level and presented in Table 2. According to Table 3, A. chroococcum MZ26 increased the essential oil percentage more than A. chroococcum MZ26, but in terms of essential oil yield, MZ26 was more effective than MZ11. The triple interaction of nitrogen, and $A$. chroococcum MZ11 and A. chroococcum MZ26 on the percentage of essential oil were significant $(\mathrm{p}<5 \%)$ (Table 2).

In the triple interaction of Nitrogen, A. chroococcum MZ11 and A. chroococcum MZ26 the highest percentage of essential oil of $0.48 \%$ was obtained from the treatment with $150 \mathrm{~kg} / \mathrm{ha}$ nitrogen and the two A. chroococcum strains, and the lowest percentage with mean of $0.38 \%$ and the lowest from the $50 \mathrm{~kg} / \mathrm{ha}$ nitrogen and the two $A$. chroococcum strains with a mean value of $0.38 \%$ (Table 5). Like the study by Akbarinia et al. (2012), fertilizer application resulted in an increase in essential oil content and essential oil yield in Trachyspermum ammi. They also stated that application of nitrogen and phosphorus up to 60 and $90 \mathrm{~kg} / \mathrm{ha}$, respectively resulted in increased grain yield size, longevity of leaves and branching, and the freshness of leaves in the plant.

\section{Essential oil yield}

The individual effect of nitrogen on essential oil yield of Mentha piperita was significant ( $\mathrm{p}<5 \%$ ) (Table 2). In this regard, the highest yield was obtained from the $A$. chroococcum strains $(55.80 \mathrm{~kg} / \mathrm{ha})$, and the lowest was related from the control of nitrogen $(25.23 \mathrm{~kg} / \mathrm{ha}$ ) (Table 3 ). According to the results, the increase in the use of nitrogen from zero to $150 \mathrm{~kg} / \mathrm{ha}$ increased the essential oil percentage and essential oil yield (Table 4). These results are a clear indication of the role of nitrogen in increasing the vegetative growth in plants, hence, increase in total dry matter yield per unit area. A close analysis of the results revealed that the triple interaction of nitrogen, $A$. chroococcum MZ11, and A. chroococcum MZ26 had the most significant effect on the percentage and yield of essential oil, which implies that the combined effect of these treatments has an enormous effect compared to their individual and cross-linking effects.

The individual effects of $A$. chroococcum MZ11 and $A$. chroococcum MZ26 on essential oil yield of Mentha piperita were significant at $1 \%$ level. (Table 2). The interactions of nitrogen fertilizer and A. chroococcum MZ11 and A. chroococcum MZ26 on the yield of essential oil were significant at $5 \%$ and $1 \%$, respectively (Table 2). According to the results, it is obvious that the $A$. chroococcum MZ11 and A. chroococcum MZ26 complemented the role of the nitrogen fertilizer to effectively meet the plant requirement. Based on the results of Table 4, the combination of these two A. chroococcum strains with nitrogen fertilizer have a greater effect on the combination of these two A. chroococcum strains together. The combined effect of $A$. chroococcum MZ11 and $A$. chroococcum MZ26 on the yield of essential oil was significant at $5 \%$ (Table 2). In this regard the highest yield of essential oil obtained $91.65 \mathrm{~kg} / \mathrm{ha}$ and the lowest yield, being $52.62 \mathrm{~kg} / \mathrm{ha}$ (Table 5). The triple interaction of nitrogen and two A. chroococcum strains on the yield of essential oil were also significant at $1 \%$ (Table 2).

Table 2. Analysis of variance of Nitrogen, A. chroococcum MZ11 and A. chroococcum MZ26 on the percentage and yield of essential oil of Mentha piperita

\begin{tabular}{llrr}
\hline \multirow{2}{*}{ SOV } & df & \multicolumn{2}{c}{ MS } \\
\cline { 3 - 4 } & & $\begin{array}{c}\text { Essential oil } \\
\text { percentage }\end{array}$ & $\begin{array}{c}\text { Essential oil } \\
\text { yield }\end{array}$ \\
\hline Replication & 2 & $1.280^{\text {ns }}$ & $6325648.333^{\mathrm{ns}}$ \\
$\mathrm{N}$ & 3 & $182.025^{*}$ & $3325416.226^{*}$ \\
Error & 6 & 20.335 & 358469.875 \\
MZ11 & 1 & $2225.036^{* *}$ & $72136548.215^{* *}$ \\
MZ11*MZ26 & 3 & $48.387^{*}$ & $2569823.7012^{* *}$ \\
MZ26 & 1 & $523.081^{* *}$ & $13269587.658^{* *}$ \\
$\mathrm{~N}^{*}$ MZ11 & 3 & $11.685^{*}$ & $2569875.325^{* *}$ \\
$\mathrm{~N}^{*}$ MZ26 & 1 & $52.431^{* *}$ & $22564.548^{*}$ \\
$\mathrm{~N}^{*}$ MZ26*MZ11 & 3 & $83.152^{*}$ & $203269.559^{*}$ \\
Error & 24 & 25.325 & 1352648.562 \\
CV $(\%)$ & - & 13.23 & 8.2 \\
\hline
\end{tabular}

Table 3. Comparison of the average effect of nitrogen, $A$. chroococcum MZ11 and A. chroococcum MZ26 on the percentage and yield of essential oil of Mentha piperita

\begin{tabular}{lcc}
\hline Treatment & $\begin{array}{c}\text { Essential oil } \\
\text { percentage }\end{array}$ & $\begin{array}{c}\text { Essential oil yield } \\
(\mathbf{k g} / \mathbf{h a})\end{array}$ \\
\hline Nitrogen $(\mathrm{kg} / \mathrm{ha})$ & & \\
0 & $0.15 \mathrm{~d}$ & $20.23 \mathrm{~b}$ \\
50 & $0.20 \mathrm{c}$ & $27.53 \mathrm{~d}$ \\
100 & $0.22 \mathrm{~b}$ & $30.45 \mathrm{~d}$ \\
150 & $0.35 \mathrm{a}$ & $45.60 \mathrm{c}$ \\
MZ11 & $0.43 \mathrm{a}$ & $55.80 \mathrm{~b}$ \\
MZ26 & $0.44 \mathrm{a}$ & $49.50 \mathrm{a}$ \\
\hline
\end{tabular}

Table 4. Comparison of the average double interaction of nitrogen, A. chroococcum MZ11 and A. chroococcum MZ26 on the Percentage and yield of essential oil of Mentha piperita

\begin{tabular}{lccc}
\hline Treatment & PGPR & $\begin{array}{c}\text { Essential oil } \\
\text { percentage }\end{array}$ & $\begin{array}{c}\text { Essential oil } \\
\text { yield (kg/ha) }\end{array}$ \\
\hline Nitrogen (kg/ha) & MZ11 & & \\
0 & & $0.25 \mathrm{~d}$ & $33.70 \mathrm{c}$ \\
50 & & $0.30 \mathrm{c}$ & $42.58 \mathrm{c}$ \\
100 & & $0.39 \mathrm{~b}$ & $53.38 \mathrm{~b}$ \\
150 & MZ26 & $0.62 \mathrm{a}$ & $80.30 \mathrm{a}$ \\
Nitrogen (kg/ha) & & $0.22 \mathrm{~b}$ & $27.26 \mathrm{~d}$ \\
0 & & $0.28 \mathrm{a}$ & $38.05 \mathrm{ab}$ \\
50 & & $0.34 \mathrm{a}$ & $44.33 \mathrm{~b}$ \\
100 & & $0.41 \mathrm{a}$ & $55.90 \mathrm{a}$ \\
150 & & $0.16 \mathrm{c}$ & $21.38 \mathrm{c}$ \\
MZ11 & & & \\
\hline
\end{tabular}


Table 5. Comparison of the average triple interaction of Nitrogen, A. chroococcum MZ11 and A. chroococcum MZ26 on the percentage and yield of essential oil of Mentha piperita

\begin{tabular}{llllc}
\hline & Average & \multicolumn{2}{c}{ Treatment } \\
\hline $\begin{array}{l}\text { Essential oil } \\
\text { yield (kg/ha) }\end{array}$ & $\begin{array}{c}\text { Essential oil } \\
\text { percentage }\end{array}$ & \multicolumn{1}{c}{ MZ26 } & MZ11 & $\begin{array}{c}\text { Nitrogen } \\
(\mathbf{k g} / \mathbf{h a})\end{array}$ \\
\hline $0.15 \mathrm{i}$ & $20.23 \mathrm{i}$ & Non-use & Non-use & 0 \\
$0.44 \mathrm{gh}$ & $49.50 \mathrm{gh}$ & Use & & \\
$0.43 \mathrm{ef}$ & $55.80 \mathrm{ef}$ & Non-use & Use & \\
$0.16 \mathrm{~cd}$ & $21.38 \mathrm{c}$ & Use & & \\
$0.20 \mathrm{i}$ & $27.53 \mathrm{i}$ & Non-use & Non-use & 50 \\
$0.28 \mathrm{~h}$ & $38.05 \mathrm{~h}$ & Use & & \\
$0.30 \mathrm{fg}$ & $42.58 \mathrm{fg}$ & Non-use & Use & \\
$52.62 \mathrm{de}$ & $0.38 \mathrm{de}$ & Use & & \\
$0.22 \mathrm{i}$ & $36.45 \mathrm{i}$ & Non-use & Non-use & 100 \\
$0.34 \mathrm{~h}$ & $44.33 \mathrm{gh}$ & Use & & \\
$0.39 \mathrm{cde}$ & $53.38 \mathrm{~cd}$ & Non-use & Use & \\
$65.09 \mathrm{~b}$ & $0.73 \mathrm{~b}$ & Use & & \\
$0.35 \mathrm{~b}$ & $45.60 \mathrm{~b}$ & Non-use & Non-use & 150 \\
$0.41 \mathrm{gh}$ & $55.90 \mathrm{i}$ & Use & & \\
$0.62 \mathrm{a}$ & $80.30 \mathrm{a}$ & Non-use & Use & \\
$91.65 \mathrm{c}$ & $0.48 \mathrm{c}$ & Use & & \\
\hline
\end{tabular}

Similarly, Banchio et al. (2009) reported that the application of biological fertilizers to basil, was very effective in increasing the biomass and yield of essential oils. Thus, the positive effects of biofertilizers such as incorporation of Aztobacter on improving the nutritional conditions in plants have been proven in this study.

According to the results obtained in this study, the application of different Aztobacter both singularly and in combination resulted in the increase in the yield of essential oil of peppermint. Thus, the incorporation of $A$. chroococcum MZ11 and A. chroococcum MZ26, especially by small-holder farmers will serve as a good alternative to application of chemical fertilizers. Generally, the use of crop techniques and environmental factors in the cultivation of crops to increase the amount of active ingredients is a very interesting and important subject matter, for example, the use of legumes as green fertilizers, nitrogen will be released gradually over a long period of time to enhance nitrogen absorption by plants during successive growing periods.

\section{ACKNOWLEDGEMENTS}

The author wishes to thank the University of Kashan, Iran for supporting this study.

\section{REFERENCES}

Afzal A, Ashraf M, Asad SA, Ahmad F, Ahmad I, Farooq M. 2010. Effect of phosphate solubilizing microorganisms on phosphorus uptake, yield and yield traits of wheat (Triticum aestivum) in rainfed area. $\mathrm{J}$ Agric Biol 7 (2): 207-209.

Akbarinia A, Rezaei MB, Tahmasebi Z, Sefidkon F, Sharifi Ashoorabadi A, Qhalavand A. 2012. Investigation of Different systems of nutrition on yield and amount of essential oil of Carum copticum Heirn seed. Iranian J Med Arom Plant Res 18: 56 -68.

Aktar MS, Hasan MK, Adhikery R, Chowdhary MK.1993. Integrated management of Sesbania rostrata and urea nitrogen in rice-rice cropping system. Ann Bangladesh Agric 3: 109-114.

Anvar M, Jalali B, Goldoos B. 2005. Evaluation of nitrogen fertilizer on medicinal plants. Mag Und Bas Pro Crops 188: 520-529.

Balyan S, Sobti N. 1990. Effect of nitrogen, phosphor and potassium on dry matter accumulation and nutrient uptake in basil (Ocimum gratissimum L.). Indian Perfumer 34 (3): 225-231.

Banchio E, Xie X, Zhang H, Pare PW. 2009. Soil bacteria elevate essential oil accumulation and emissions in sweet basil. J Agric Food Chem 57: 653-657.

Bist L.D, Kewaland C.S, Pandey S. 2000. Effect of planting geometry and $\mathrm{N}$ levels on growth yield and quality of Europen oil (Anethum graveolens). Ind J Heart. 57 (4): 351-355.

Blumenthal M. 1998. The Complete German Commission E Monographs: Therapeutic Guide to Herbal Medicines. Ameican Botany Council, Austin.

Cherr CM, Scholberg JMS, McSorley R. 2016. Green manure approaches to crop production: a synthesis. J Agric 98: 302-319.

Ebhin Masto R, Chhonkar PK, Singh D, Patra AK. 2006. Changes in characteristics in a long-term field trial on a sub-soil biological and biochemical tropical inceptisoil. Soil Bio Biochem 38: 1577-1582.

Fleming T. 1998. PDR for Herbal Medicine. 2nd ed. Medical Economics Company, Montvale, NJ

Govedarica M, Miliv V, Gvozdenoviv DJ. 2003. Efficiency of the association between Azotobacter chroococcum and tomato varieties. Plant Soil 42: 113-120.

Imam Y, Niknejad M. 2014. Introduction to Physiology of Crop Yields. Shiraz University Press, Shiraz, Iran.

Loomis WD, Corteau R. 1972. Essential oil biosynthesis. Rec Adv Phytochem 6: 147-185.

Malekooti M. 2018. Sustainable Agriculture and Increasing Yield by Optimizing Fertilizer Use in Iran. 1st ed. Agri Edu Press, Karaj, Iran.

Masto RE, Chhonkar PK, Singh D, Patra AK. 2006. Changes in soil biological and biochemical characteristics in a long-term field trial on a sub-tropical inceptisol. Soil Biol Biochem 38: 1577-1582.

Murrray MT. 1995. The Healing Power of Herbs: The Enlightened Person's Guide to The Wonders of Medicinal Plants. Prima Pub., Rocklin, CA.

Okon Y, Labandera-Gonzalez C.A. 1994. Agronomic applications of Azospirillum: an evaluation of 20 years of world wild field inoculation. Soil Biol Biochem 26: 1591-1601.

Peirce A. 1999. The American Pharmaceutical Association Practical Guide to Natural Medicines. 2nd ed. William Morrow and Company, Inc., New York.

Pramanik MYA, Sarkar MAR, Islam MA, Samad MA. 2004. Effect of green manures and different levels of nitrogen on the yield and yield components of transplant Aman Rice. J Agron 3: 122-125.

Singh VP, Chatterjee BN. 1989. Response of mint species to nitrogen fertilization. J Agric Sci 113: 2, 267-271.

Valid Abadi AS, Rahmani R, Daneshian N, Bigdeli M. 2008. Effect of different levels of drought stress and nitrogen on (oil yield in medicinal Calendula officinalis. Iranian J Med Aromat Plant Res 1 (39): 101-115.

Zaied KA, Abd-El-Hady AH, Afify AH, Nassef MA. 2003. Yield and nitrogen assimilation of winter wheat inoculated with new recombinant inoculants of rhizobacteria. Pakistan J Biol Sci 6: 344358 . 